\title{
Rasa nyeri pada mukosa jaringan pendukung gigitiruan penuh dan penanggulangannya Pain on supported tissue mucosa of full denture and its relief
}

\author{
Taufik Sumarsongko, Aprillia Adenan \\ Bagian Prostodonsia Fakultas Kedokteran Gigi \\ Universitas Padjadjaran \\ Bandung, Indonesia
}

\begin{abstract}
Dentures painful and uncomfortable at alveolar ridge denture support of oral mucosa is the most common symptom of denture wearers. The aim of this article is to provide guidelines for optimal using of the media and to identify alternative uses that could be considered in daily practice. Soreness of oral mucosa under a denture, like all pain is complex uncomfort experience, in which multitude of factors interact from the emotional to the physical. Uneven pressure on tissue support under a denture base is probably initially caused irritate to denture bearing tissue, contribute to causing inflamation and increased sensitivity. It should be possible to identify which of the major etiological agent is causing the pain and rapidly treatment.
\end{abstract}

Key words: soreness, full denture, tissue support, management

\begin{abstract}
ABSTRAK
Rasa nyeri dan ketidaknyamanan pada mukosa lingir alveolar pendukung gigitiruan, merupakan keadaan umum yang sering dirasakan oleh pasien yang memakai gigitiruan. Kajian ini bertujuan memberi petunjuk yang optimal mengenai penggunaan media untuk identifikasi daerah penyebab rasa nyeri yang dapat digunakan sehari-hari. Rasa nyeri yang disebabkan oleh gigitiruan seperti semua rasa nyeri merupakan pengalaman yang tidak menyenangkan, yang terjadi dari interaksi banyak faktor, mulai dari emosional hingga fisik. Tekanan basis gigitiruan yang tidak merata pada mukosa lingir alveolar jaringan pendukung, biasa merupakan penyebab awal terjadinya iritasi pada jaringan mukosa, akan mendukung terjadinya peradangan dan meningkatkan sensitivitas mukosa. Jadi merupakan suatu keharusan untuk mengidentifikasi etiologi utama dan menanggulangi segera penyebab rasa nyeri pada pasien.

Kata kunci: nyeri, gigitiruan penuh, jaringan pendukung gigitiruan, penatalaksanaan
\end{abstract}

Koresponden: Taufik Sumarsongko, Jl. Margahayu Raya Barat Blok I-2 No. 4, Bandung. E-mail: taufik_sumarsongko@yahoo.com

\section{PENDAHULUAN}

Rasa nyeri pada mukosa jaringan pendukung gigitiruan sering dijumpai pada pasien yang memakai gigitiruan penuh (GTP). ${ }^{1}$ Kadangkadang gejala rasa nyeri dapat berupa rasa gatal, pedih, panas/rasa terbakar dan mukosa jaringan pendukung sangat sensitif. ${ }^{2}$

Penderita dengan perasaan nyeri tidak merasa nyaman memakai gigitiruan, malahan ada yang menderita nyeri yang berlebihan, sehingga tidak mampu memakai gigitiruannya. Hal tersebut membuat pasien tidak puas terhadap operator yang membuatnya. Rasa sakit biasanya disertai dengan kerusakan jaringan, tetapi ada juga secara klinis terjadi kerusakan jaringan mukosa, tetapi tidak disertai nyeri. ${ }^{2,3}$

Pada umumnya penyebab rasa nyeri pada pemakai gigitiruan multi faktor. Bbisa disebabkan oleh emosi, fisik, gangguan metabolisma/ hormonal, dan gangguan gizi. ${ }^{3}$ kekurangan gizi dan metabolisma, seperti defisiensi zat besi, kekurangan protein, penyerapan usus yang kurang baik, sebagai penunjang penyebab nyeri mulut. Tanda yang sudah jelas menimbulkan rasa nyeri adalah memiliki lingir yang rendah dengan jaringan hiperplastik, dan adanya ulser. ${ }^{2}$

Tekanan di bawah gigitiruan bisa merupakan penyebab awal terjadinya iritasi kemudian menyebabkan rasa nyeri. ${ }^{4}$ Jaringan pendukung yang rusak tersebut akan mengeluarkan substansi histamin dan prostaglandin dan saraf terakhir mengeluarkan substansi $\mathrm{P}$, mendukung terjadinya inflamasi dan meningkatkan sensitivitas. ${ }^{2,3}$

Dalam makalah ini akan dibahas mengenai pemeriksaan dan diagnosis rasa nyeri pada pemakai gigitiruan, dan tatacara menemukan penyebab utama, dan penanggulangan nyeri pada penderita memakai GTP.

\section{TINJAUAN PUSTAKA \\ Penyebab rasa nyeri di mukosa akibat gigitiruan}

Berdasarkan bentuk anatomi dan fisiologi jaringan pendukung gigitiruan, 2 jenis mukosa 
yang menutupi lingir, yaitu mukosa mastikatori di puncak lingir ditutupi keratin yang biasanya memiliki ketebalan $4 \mathrm{~mm}$, dan mukosa lining yang non keratin ketebalannya $0,3 \mathrm{~mm}$. Mukosa lining menutupi dasar mulut, genial tubercle, dan mylohyoid ridge. Adanya perbedaan ketebalan ini memberikan dampak mengganggu kemampuan mukosa untuk dapat menerima tekanan yang sama dari basis gigitiruan. Mukosa yang tipis, lebih dulu merasakan tekanan beban yang diteruskan dari basis gigitiruan dari pada mukosa yang tebal (Gbr.1).,3

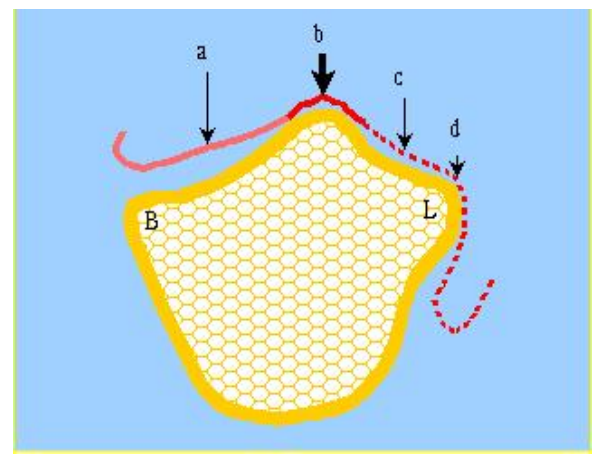

Gambar 1. Suatu bagian lingir regio molar rahang bawah. Tanda panah dan ketebalan mengindikasikan kelenturan mukosa terhadap beban. Mukosa (a) di atas buccal shelf (B) mudah bergerak, lentur, dan cukup tebal. Mukosa (b) yang melekat kuat melapisi permukaan tulang dan kurang lentur. Daerah lingual (L) mukosa (c) sangat tipis dan mudah bergerak. Beberapa daerah di atasnya lentur tetapi daerah di atas tepi tulang (d) tidak lentur.

Bentuk permukaan tulang bervariasi mulai dari membulat hingga tajam, bergantung pada pola resorpsi. Lingir alveolar ada yang tajam seperti jarum yang berada di bawah mukosa. ${ }^{3}$

Kemampuan mukosa menerima beban dari GTP RB sekitar $1 / 2$ dari yang diterima RA. ${ }^{4}$

Suplai darah dari mukosa lingir alveolar berasal dari pembuluh darah supraperiosteal. Pada mukosa puncak lingir terdapat suplai darah kolateral dari tulang pada bagian bukal, labial dan lingual. Adanya tekanan di mukosa yang menghalangi suplai darah menyebabkan suplai darah kolateral dari tulang tidak lancar sehingga, jaringan menjadi rusak. ${ }^{3}$

Mukosa bersifat viskoelastik, yang artinya terdapat aspek elastisitas dan viskositas bersamaan di dalam dukungan, walaupun mukosa kurang elastis dibandingkan dengan ligamen periodontal. Kedua sistem dukungan ini menyerupai suspensi pada mobil. Ligamen periodontal disuplai dengan baik oleh fiber berperan seperti pegas menahan tekanan dan akan memantul kembali saat ban (sebagai beban) berpindah tempat. Mukosa sebagai shock absorber berfungsi sebagai peredam yang memperlambat kecepatan perpindahan. Ligamen ini menahan beban dengan baik dan mengembalikan posisi gigi dengan cepat terutama bila beban yang terjadi besar dan cepat (gambar 2). ${ }^{3,5}$

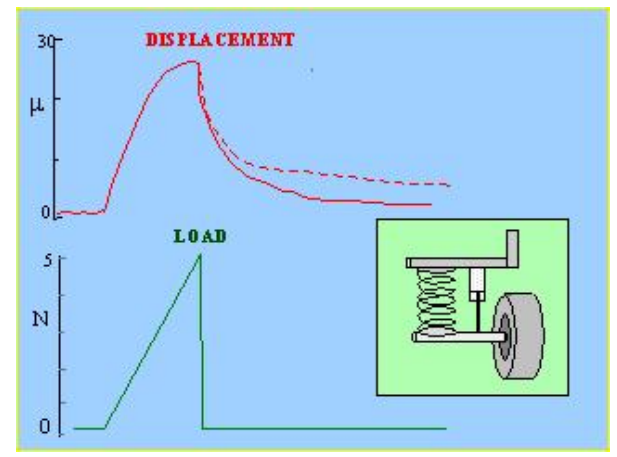

Gambar 2. Bila gigi diberi beban $5 \mathrm{~N}$, terjadi peningkatan pertahanan viscous yang progresif kepada perpindahan. Bila beban dihilangkan, gigi membutuhkan beberapa detik untuk kembali ke posisi semula. Seiring dengan pertambahan usia (garis yang terputus) pengembalian posisi gigi lebih lama. Dukungan mukosa dan gigi keduanya elastik (pegas) dan viscous (peredam), seperti pada kendaraan bermotor.

terus-menerus, ıebin terınat pada mukosa mulut, karena kurangnya fiber elastis dan vaskularisasi dibanding ligamen periodontal. Jika penyembuhan mukosa mulut pada beban yang intensitasnya panjang membutuhkan beberapa jam, pada pasien yang sudah tua membutuhkan beberapa hari. Pada kasus clenching yang berlanjut menyebabkan perubahan pada mukosa, iskemi dan kerusakan yang lebih luas (Gambar 3)

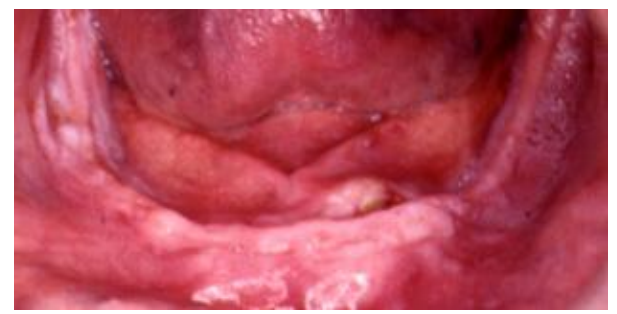

Gambar 3. Mukosa RB membengkak dan memerah karena clenching yang berulang. Tidak ada penyesuaian dari gigitiruan yang akan menghilangkan rasa sakit di gigitiruan.

\section{Beberapa hal yang menyebabkan gigitiruan lebih sering menyebabkan sakit}

Bila tekanan didistribusikan secara merata pada mukosa mulut yang terletak antara tulang dan gigitiruan, bintik-bintik merah (sore spots) jarang terjadi. ${ }^{3}$ 
Basis gigitiruan dari bahan akrilik heat-cured menyusut sedikit saat curing, sehingga mempengaruhi ketepatannya, terutama gigitiruan rahang bawah. Oleh karena itu gigitiruan rahang bawah sering mempunyai retensi yang kurang baik.

Distribusi dari beban kunyah sangat besar saat gigi melakukan kontak berkelanjutan, setidaknya dekat area antartonjol yang maksimal. Bila terdapat kontak gigi yang prematur pada salah satu area di oklusal, beban akan terkonsentrasi, dan tekanan pada mukosa meningkat pada area tersebut.

Pencatatan hubungan rahang yang tepat sangat penting, karena tekanan yang tidak seimbang pada galengan gigit dapat menghasilkan kontak prematur pada gigitiruan. Hal ini sangat penting untuk bahan pencatatan hubungan rahang harus mempunyai kelenturan yang cukup yang akan dipindahkan oleh galengan gigit. Untuk alasan ini, gips cetak antara tanggul sangat ideal, tetapi low fusing wax, yang mengandung metal (Aluwax) dapat juga digunakan.

Remounting setelah curing akrilik adalah tahap yang penting, karena kesalahan saat penyusutan dapat dikoreksi. Pada kunjungan terakhir, oklusi diperiksa kembali menggunakan wax indikator oklusi. Kertas artikulasi kurang dapat mencatat secara akurat, terutama pada basis yang tidak stabil. Wax indikator memberikan informasi tambahan mengenai tebal gigi yang harus dikurangi sehingga oklusinya berimbang.

Tinggi vertikal yang berlebih dapat menyebabkan clenching, selain merupakan penyebab utama ketidaknyamanan dan kesulitan dalam mengunyah dan menelan.

Basis gigitiruan harus dapat mengakomodasi perbedaan tulang yang tajam dan mukosa tipis dengan pembedahan untuk mengurangi ketajaman tulang alveolar (gambar 4), menggunakan basis yang lunak, pencetakan alternatif, ${ }^{3}$ dan pemakaian pasta indikator. ${ }^{6,7}$

Pencetakan alternatif dilakukan untuk mencatat perbedaan kelenturan dari mukosa dengan bahan mukokompresif, sehingga seluruh daerah dapat berkontribusi untuk mendukung gigitiruan. Salah satu metoda pencetakan dengan relining memakai bahan tissue conditioner (De Treys Viscogel seperti terlihat pada Gambar 5. Selain itu pencetakan dapat memakai bahan mukostatik, sehingga dapat digerakan oleh otot serta jaringan lunak dan pembentukan akhiran yang menekan tidak terjadi (bahan zinc oxide atau kompon lunak). ${ }^{3}$
Pemakain pasta indikator dimaksudkan untuk mengetahui daerah pada basis GT yang menyebabkan tekanan berlebih sehingga menyebabkan rasa nyeri. Setelah daerah yang menekan diketahui, selanjutnya dilakukan peredaan. Pasta indikator tersedia nonsetting and cream-based (Pressure Indicator Paste; Mizzy, Inc, Cherryl Hill, $\mathrm{Nj}$ ), nonsetting aerosol powders (Occlude; Pascal Intl, Inc, Belleveu, Wash), atau media polymetisze (Typically catalyst/base elastomer missal Fit Checker; GC Corp.Tokyo, Japan). ${ }^{6,7}$

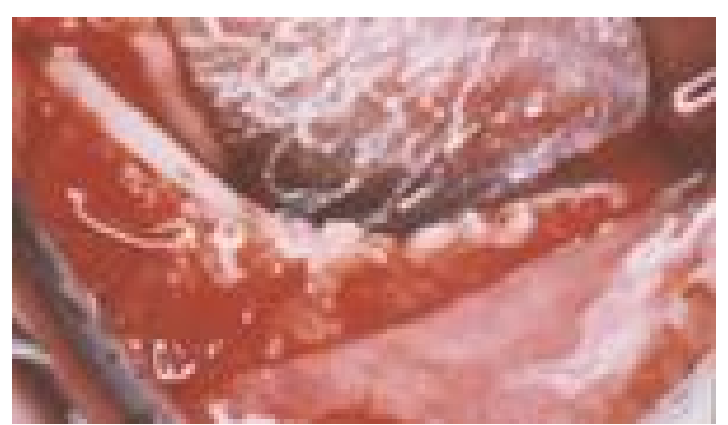

Gambar 4. Mukosa RB dibuka untuk mengurangi tulang tajam agar terbentuk dukungan yang lebih nyaman.

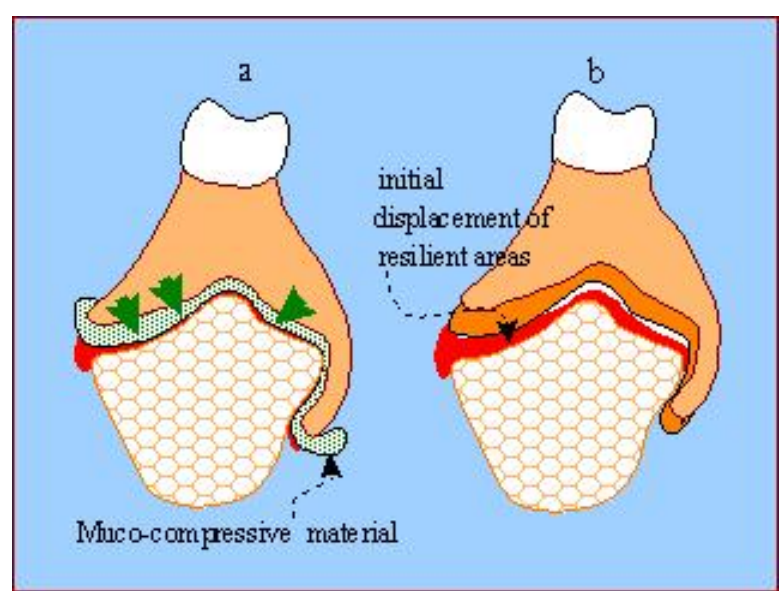

Gambar 5.A. Gigitiruan RB di-reline menggunakan tissue conditioner sebagai bahan pencetak fungsional. Bagian yang lentur dari mukosa (panah hijau) tertekan, B. Fitting surface gigitiruan yang di-rebase menekan daerah yang lentur sehingga saat basis mulai menyalurkan tekanan yang lebih besar, ke seluruh mukosa denture bearing berkontribusi untuk menyalurkan daya gigit pada tulang di bawahnya.

\section{Teknik aplikasi pasta indikator ${ }^{6}$}

Sebelum mengaplikasian pasta, bagian gigitiruan yang tajam diasah untuk meminimalkan ketidaknyamanan, periksa adaptasi basis sebelum dilakukan penyesuaian oklusi, gigitiruan harus dikeringkan sehingga bahan pasta melekat pada 

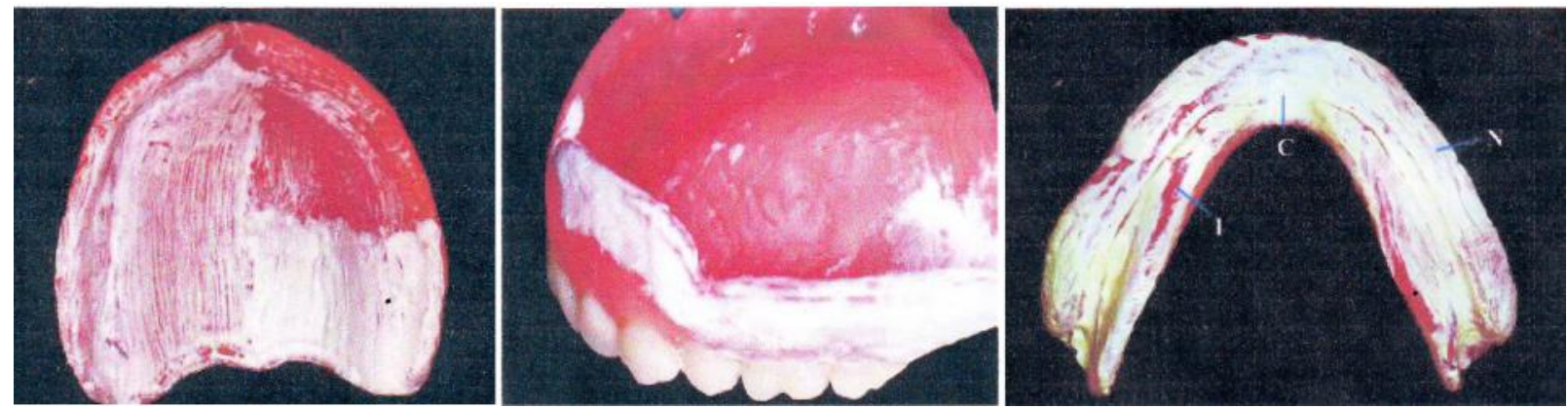

Gambar 6.A. Gigitiruan diulasi pasta secukupnya sehingga basis menjadi warna primer dari bahan. Kanan atas bahan yang terlalu sedikit, kanan bawah bahan terlalu banyak, akan membuat interprestasi lebih sulit ditentukan. B. Bahan diaplikasi secara tepat di atas tepi sayap pada permukaan bukal. Bagian tepi sayap yang terbuka menunjukkan daerah overextend dan overcontour sehingga perlu dikoreksi. C. $\mathrm{N}$ adalah jaringan yang tidak kontak, tampak ulasan pasta. $\mathrm{C}$ adalah daerah yang tidak tampak ulasan pasta, menunjukkan kontak yang diharapkan. I adalah daerah tanpa pasta, menunjukkan daerah yang tertekan.

permukaan gigitiruan dan mukosa mulut dibiarkan basah, supaya pasta tidak melekat pada mukosa. Selanjutnya, bahan diaplikasi secara merata secukupnya pada basis menggunakan sikat, sehingga basis berwarna seperti bahan pasta. Apabila bahan terlalu sedikit atau terlalu banyak akan menyulitkan interprestasi (Gambar 6A). indikator diaplikasikan di tepi sayap gigitiruan, untuk mengevaluasi panjang sayap dan penekanan frenulum (Gambar 6B).

Kaca mulut digunakan untuk mendorong komisura pada saat memasukkan gigitiruan, sehingga pasta tidak terhapus. Bila gigitiruan tidak dapat dimasukkan tanpa menyentuh bibir atau pipi, maka evaluasi dilakukan satu sisi terlebih dahulu.

Kedudukan gigitiruan saat uji coba adaptasi, dengan tekanan awal yang ringan supaya pasien merasa nyaman. Selanjutnya dilakukan tekanan yang konstan daerah molar pertama, instruksikan kepada pasien menggigit cotton rolls menggunakan tekanan yang konstan di posterior. Jangan sampai terjadi kontak oklusal yang menyebabkan gigitiruan miring dan merubah distribusi tekanan. Bila menggunakan tekanan tangan, gunakan tekanan secara konstan. Bila tekanan ditingkatkan akan menambah daya alir bahan. Jangan menggunakan pada bagian palatum gigitiruan RA, karena beban fungsional tidak terjadi pada bagian ini. Untuk mengontrol tekanan bila gigitiruan bergerak, tekanan diarahkan tegak lurus bidang oklusal. Gigitiruan jangan digerakan, ketika sudah tepat pada kedudukannya.

Untuk mengevaluasi panjang sayap saat memeriksa overekstensi di daerah mukosa bergerak dan frenulum, gigitiruan harus stabil ketika operator memanipulasi pipi, bibir.

Untuk interprestasi pasta nonsetting, dikenal tiga pola pasta yaitu daerah yang masih ada ulasan pasta menunjukkan daerah yang tidak kontak dengan jaringan, daerah tidak tampak ulasan pasta tetapi tidak terhapus menunjukkan kontak yang dapat diterima, dan daerah tanpa pasta, menujukkan daerah tekanan yang berlebih (Gambar 6C).

Riwayat nyeri dapat menjadi lebih komprehensif dalam menegakkan diagnosis. Beberapa pertanyaan penting adalah "apakah bermasalah dengan pemakaian gigitiruan anda, kapan anda mulai merasakan nyeri, makanan apa yang dapat dan yang tidak dapat anda makan, adakah hal-hal yang anda lakukan untuk mengurangi rasa nyeri, bagaimana perasaan anda secara keseluruhan, dan bagaimana anda mengatasi masalah dalam hidup."3

Sebelum pemeriksaan keadaan mulut, dilakukan pemeriksaan pada gigitiruan mengenai free way space dan oklusi yang memadai. Evaluasi dimensi vertikal dari oklusi dapat dilakukan dengan calipers, Willis gauge, atau hanya dengan melihat secara dekat pada saat posisi istirahat dan intercusp. Bisa juga dengan melihat dan mendengar suara desis "s", dengan menghitung dari 60-70. Celah kurang dari $1 \mathrm{~mm}$ diantara insisivus, atau suara berisik pada gigi belakang adalah tanda pasti tidak memadainya free way space. Kertas artikulasi jarang dapat memperlihatkan catatan oklusal dan kontak prematur sebaik menggunakan wax pencatat oklusi. $^{1,6}$

Pada pemeriksaan intra oral, mukosa oral yang kering dan lengket adalah satu tanda terdapat faktor sistemik yang menyebabkan terjadinya kerusakan jaringan dan proses penyembuhan yang lama. Tekanan dengan jari di atas tulang dapat mengetahui adanya tulang yang tajam pada beberapa daerah, atau lebih difus dan keadaan 
umum yang dapat menyebabkan terjadinya kebiasaan clenching atau mengunyah makanan keras.

Diagnosis merupakan suatu keharusan untuk mengidentifikasi etiologi utama penyebab rasa nyeri pada pasien. Meskipun demikian, mungkin saja terdapat lebih dari satu faktor. Penjelasan lebih jauh kepada pasien dapat menggunakan sebuah skema sederhana (Gambar 7). Jika melibatkan lebih dari satu faktor, usaha menghilangkan rasa nyeri menjadi rumit karena juga membutuhkan partisipasi penderita dalam memperbaiki situasi.

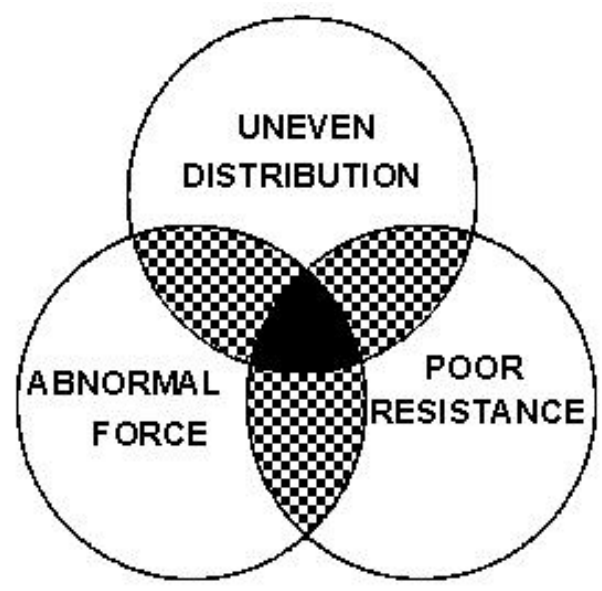

Gambar 7. Diagram simpulan dari interaksi antara tiga faktor utama yang menyebabkan nyeri pada saat penggunaan gigitiruan. Faktor tunggal mungkin tidak menyebabkan rasa nyeri, tetapi jika dikombinasikan dengan satu atau dua faktor lainnya, nyeri mengalami peningkatan dan lebih sulit untuk dikurangi (Sumber: Wilding RJC. Available at: http// www.eclipse.co.uk/mordent/denpain.htm. Accessed on 2010). ${ }^{3}$

Penanganan distribusi tekanan yang tidak merata dilakukan dengan bedah pre-prostetik untuk membuang tulang yang tajam, menggunakan bahan cetak mukokompresif, menggunakan bahan pencetak rahang dengan kekentalan rendah, try in gigitiruan sebelum proses flasking, permukaan yang sesuai dilakukan dengan pasta indikator tekanan, selalu menggunakan wax pencatat oklusal pada tahap penyelesaian, menggunakan tissue conditioner sebagai bahan cetak fungsional, dan menggunakan pelapis basis gigitiruan yang lentur.

Penanganan adanya tekanan yang berlebih dilakukan dengan mengurangi kebiasaan clenching, melepas gigitiruan ketika tidak sedang makan, pembuatan gigitiruan dengan mengurangi dimensi vertikal, dan penggunaan implan yang mendukung gigitiruan. Sedangkan penanganan daya tahan mukosa yang buruk dapat dilakukan dengan suplemen diet, melepaskan gigitiruan, dan rujuk untuk pemeriksaan medis. Pada kebanyakan kasus, rasa nyeri pemakaian gigitiruan RB dapat diperbaiki dengan penambahan tissue conditioner (Viscogel, De Trey) cukup tebal untuk meredam tekanan.

\section{PEMBAHASAN}

Konsep nyeri adalah rasa sensorik yang tidak dinginkan dan merupakan gabungan dari pengalaman emosional dengan kerusakan jaringan. Korelasi antara rasa nyeri dan kerusakan selalu berhubungan. Rasa nyeri selalu bersifat subjektif. ${ }^{8}$ Nervus trigeminalis merupakan saraf yang dominan, yang menyampaikan impuls sensorik dari area orofasial ke SSP.,

Ada beberapa pasien yang tidak pernah dapat beradaptasi dengan gigitiruannya. Kebanyakan dari mereka tidak memiliki keinginan, atau tidak dapat belajar untuk membiasakan, atau mentoleransi ketidaknyamanan pada awal pemakaian gigitiruan. ${ }^{3}$

Telah disebutkan bahwa clenching sebagai penyebab utama dari nyeri dalam pemakaian gigitiruan. Memakai gigitiruan pada malam hari dapat menyebabkan nyeri pada pemakaian gigitiruan, menghambat penyembuhan; untuk itu aturan-aturan umum harus dijelaskan termasuk melepas gigitiruan pada malam hari. Pasien dengan single denture tunggal $\mathrm{RB}$ berisiko menderita nyeri pada mukosa. Hal ini mungkin karena, ligamen periodontal menyediakan titik balik positif pada otot-otot mastikasi yang meningkatkan kekuatan kontraksi. Mukosa mulut kemungkinan dipengaruhi oleh kelainan sistemik seperti diabetes, anemia, defisiensi nutrisi dan usia lanjut. ${ }^{2,3}$ Kekeringan pada mulut yang berkombinasi dengan pengurangan jumlah sel, membuat mukosa rentan mendapat trauma dan lambat dalam proses penyembuhan. Umumnya kondisi ini berada di luar kontrol pengguna gigitiruan.

Gambaran klinis mukosa mulut pada proses menua adalah atrofi. Jumlah lapisan epitel menurun, dan ketebalan pada mukosa dan submukosa menurun. Penipisan jaringan yang sebenarnya, disertai dengan menurunnya kemampuan memperbaiki diri, menjadikan mukosa pendukung gigitiruan rapuh dan mudah terluka. Sensitivitas mukosa ini mungkin berkaitan dengan bergesernya keseimbangan air dari ruang 
interseluler ke ruang ekstraseluler jaringan. Menurunnya fungsi ginjal juga dapat berakibat dehidrasi pada jaringan, yaitu sel-sel jaringan mengalami kekurangan nutrisi. Pada pasien muda yang tidak bergigi cenderung mempunyai mukosa pendukung gigitiruan dan submukosa yang cukup tebal. Sebaliknya, mukosa pada orang tua tidak bergigi biasanya tipis dan sangat meregang, serta mudah memucat. Mukosa yang berkurang ketebalannya mungkin berkaitan dengan berkurangnya tinggi alveolar, karena atrofi epitel mengakibatkan berkurangnya lapisan sel epitel dan ketebalan jaringan ikat di bawahnya, juga terlihat sebagai penurunan luas daerah permukaan mukosa mulut. Sebaliknya, hal ini memberikan tekanan pada alveolar di bawahnya. Tekanan pada tulang sedikit banyak ditahan oleh tulang itu sendiri, dan akitivitas inilah yang terjadi pada proses resorpsi. ${ }^{2}$

Dari penjelasan di atas mengenai pembahasan tentang pembagian tekanan ke jaringan pendukung gigitiruan, menjadi sangat relevan bila yang dihadapi adalah pasien dengan dukungan mukosa yang tidak adekuat. Jaringan mukosa demikian memerlukan perawatan ekstra, yaitu sering diberi bahan pelapis lunak dan nasehat tentang pembersihan dan perawatan jaringan.

\section{SIMPULAN}

Mengetahui riwayat nyeri, pemeriksaan gigitiruan dan jaringan pendukung dengan teliti merupakan faktor utama dalam menegakan diagnosis rasa nyeri dan menentukan perawatannya. Rasa nyeri dapat disebabkan oleh distribusi beban kunyah yang tidak merata, baik akibat permukaan tulang yang tajam, jaringan pendukung mukosa yang tidak merata, dimensi vertikal yang berlebih, dan oklusi yang tidak tepat.

\section{SARAN}

Kepada para klinisi diharapkan untuk mengikuti prosedur pembuatan gigitiruan secara teliti, memeriksa jaringan pendukung dengan pasta indikator dan mengasah bila ada kelainan tekanan berlebih pada gigitiruan. Bila pasien mengeluh nyeri, lepas gigitiruan sepanjang hari, kecuali pada saat makan; atau menggunakan bahan tissue conditioner.

\section{DAFTAR PUSTAKA}

1. Marstad AT. Postinsertion denture problems. J Prosthet Dent 1986: 19: 126-32.

2. Hickey JC, Zarb GA, Bolender CC. Boucher prosthodontic traetment for edentulous patient. $9^{\text {th }}$ Ed. Philadelphia: The C.V Mosby Company; 1985.p. 30-9.

3. Wilding RJC. Available at: hltp//www.eclipse. co.uk/mordent/denpain.htm. Accessed on 2010

4. Suzuki. Pressure pain threshold of mucosa under removable complete denture. Yokohama: Tsurumi University; 2005.

5. Picton DCA, Wills DJ. Viscoelastic proportion of the periodontal ligament and mucous membrane, $\mathrm{J}$ Prosthet Dent 1978; 40: 263-72.

6. Loney RW, Knechtel. Diagnosing denture problem using pressure-indicating media. J Prosthet Dent 2009; 101: 137-41.

7. Carr AB, McGivney GB, Brown DT. McCracken's removable partial prosthodontics. $11^{\text {th }}$ Ed. St.Louis: Mosby; 2004. p. 363-72.

8. Green M, Glick M. Burkets oral medicine, diagnosis dan treatment. $10^{\text {th }}$ Ed. St. Louis: BC Decker Inc. 